Available online at website :

http://uinjkt.ac.id /index.php/elementar

Elementar (Elementary of Tarbiyah): Jurnal Pendidikan Dasar, 1(1), 2021, 50-58

\title{
Pengaruh Motivasi Belajar dan Kedisiplinan Saat Home Learning terhadap Hasil Belajar IPS Kelas IV MI Al-Mursyidiyyah
}

\author{
Linda Malika'), Takiddin ${ }^{2)}$ \\ Pendidikan Guru Madrasah Ibtidaiyah, FITK, UIN Jakarta \\ Jl. Ir H. Juanda No.95, Kota Tangerang Selatan \\ E-mail:linda.malika@mhs.uinikt.ac.id
}

\section{Corresponding}

Author: Linda Malika ${ }^{1}$,

Takiddin ${ }^{2}$

Submit: 17 September

2020

Revisi: 18 November 2020

Approve: 12 Januari 2021

Pengutipan: Linda Malika

\& Takiddin. (2021). Upaya

Pengaruh Motivasi Belajar dan Kedisiplinan Saat Home

Learning terhadap Hasil

Belajar IPS Kelas IV MI Al-

Mursyidiyyah. Elementar

(Elementary of Tarbiyab): Jurnal

Pendidikan Dasar, 1(1), 2021,

50-58. elementar.v1i1.

20887.

\section{Abstract}

The research objective was to determine how much influence the learning motivation and discipline at home learning have on social studies learning outcomes in class IV MI Al-Mursyidiyyah. This research is an ex-post facto research. The sample selection uses the simple random sampling technique Probability Sampling. Collecting data using questionnaires and documentation. The data collection method used a questionnaire and documentation. Data analysis using percentage descriptive analysis and multiple regression analysis. The results of the analysis show that the correlation coefficient $(\mathrm{Ry}(1,2))$ is 0.306 , the correlation coefficient is positive, so there is a positive influence on learning motivation and discipline variables during Home Learning on social studies learning outcomes. The coefficient of determination (R2y $(1,2)$ ) is 0.093 or $9.3 \%$, which means that learning motivation and discipline during Home Learning can explain $9.3 \%$ changes in learning outcomes.

Keywords: Learning Motivation, Discipline During Home Learning, Learning Outcomes

\begin{abstract}
Abstrak
Tujuan penelitian untuk mengetahui seberapa besar pengaruh motivasi belajar dan kedisiplin saat Home Learning terhadap hasil belajar IPS kelas IV MI Al-Mursyidiyyah. Penelitian ini termasuk jenis penelitian ex-post facto. Pemilihan sampel menggunakan teknik Probability Sampling jenis simple Random Sampling. Pengumpulan data menggunakan metode angket dan dokumentasi. Metode pengumpulan data menggunakan angket dan dokumentasi. Analisis data dengan menggunakan analisis deskriptif presentase dan analisis regresi berganda. Hasil analisis diperolah harga koefisien korelasi $\left(\mathrm{R}_{\mathrm{y}}(1,2)\right)$ sebesar 0,306, koefisien korelasi tersebut bernilai positif maka terdapat pengaruh positif variabel motivasi belajar dan kedisiplinan saat Home Learning terhadap hasil belajar IPS. Nilai koefisien determinasi $\left(\mathrm{R}^{2} \mathrm{y}(1,2)\right)$ sebesar 0,093 atau 9,3\% yang berarti bahwa motivasi belajar dan kedisiplinan saat Home Learning mampu menjelaskan 9,3\% perubahan hasil belajar.
\end{abstract}

Kata kunci: Motivasi Belajar, Kedisiplinan Saat Home Learning, Hasil Belajar. 



\section{PENDAHULUAN}

Pendidikan diharapkan mampu mendidik siswa menjadi pribadi yang memiliki kemampuan akademik yang dapat menerapkan, serta mengembangkan ilmu pengetahuan. Oleh karena itu, dunia pendidikan dituntut untuk terus berkembang dan berinovasi dalam melakukan perbaikan-perbaikan di segala ruang lingkup pendidikan.

Ditambah wabah COVID-19 yang melanda Indonesia menuntut semua siswa dan guru untuk melakukan kegiatan Home Learning saat pandemi virus Corona (COVID-19). Menurut Natalia Ridwan, dkk (2018) Home Learning adalah konsep pendidikan berbasis rumah yang dikelola secara mandiri oleh orang tua. Sistem ini dapat menjadi alternatif bagi ayah bunda yang menginginkan pendidikan sesuai dengan kebutuhan putra putrinya. Dimana untuk melakukan kegiatan belajar di rumah (Home Learning) orang tua dituntut untuk mendidik anak, mulai dari minat hingga gaya belajar. Dalam proses pemahaman itu akan menimbulkan kedekatan antar keduanya, baik secara fisik maupun emosi pada saat kegiatan belajar itu dilakukan sebagai tolok ukur yang digunakan untuk mengukur keberhasilan siswa dalam memahami pelajaran maupun sebagai bahan evaluasi bagi pengajar dalam menyampaikan materi pembelajaran. Hasil belajar siswa dapat dipengaruhi oleh berbagai faktor, akan tetapi faktor yang sangat mempengaruhi hasil belajar siswa biasanya timbul dari dalam diri siswa tersebut. Beberapa faktor tersebut di antaranya adalah faktor kedisiplinan belajar serta faktor motivasi belajar.

Menurutt Tu'u Tulus

Kedisiplinan belajar merupakan bentuk pengendalian diri yang dilakukan dengan kesadaran maupun karena dorongan dari pihak lain untuk melakukan kegiatan belajar. Disiplin akan terwujud melalui pembinaan yang dilakukan sejak dini mulai dari lingkungan keluarga dan berlanjut dalam pendidikan di sekolah. Keluarga dan sekolah menjadi tempat penting bagi perkembangan disiplin belajar siswa. Dapat dikatakan bahwa disiplin belajar terbentuk bukan secara otomatis sejak manusia dilahirkan, melainkan terbentuk karena pengaruh lingkungannya. Disiplin sebagai suatu kondisi yang tercipta dan terbentuk dari serangkaian perilaku yang menunjukkan nilai ketaatan, kepatuhan, kesetiaan, keteraturan atau ketertiban. Apabila aturan belajar yang telah dibuat dilaksanakan oleh siswa secara continue (terus-menerus), maka siswa akan memiliki disiplin belajar yang baik.

Dalam hal belajar, siswa yang disiplin akan mudah dalam menyerap materi pelajaran dibanding siswa yang tidak disiplin. Hal ini dikarenakan siswa yang 
disiplin dalam belajar akan senantiasa meluangkan waktu setiap harinya untuk belajar atau kegiatan yang bermanfaat. Maka dari itu, kedisiplinan belajar sangat berpengaruh pada prestasi belajar siswa.

Faktor lain dalam individu siswa yang mempengaruhi belajar adalah faktor motivasi belajar siswa. Motivasi belajar merupakan sebuah keinginan kuat yang timbul dalam diri siswa untuk mampu memahami, menguasai dan menyerap segala materi yang disampaikan guru pada saat proses pembelajaran. Tanpa adanya motivasi dalam individu siswa, maka hasil pembelajaran tidak akan tercapai secara maksimal.

Berdasarkan hasil observasi awal yang dilakukan peneliti di MI AlMursyidiyyah, diperoleh informasi bahwasannya sekolah ini telah melaksanakan pembelajaran yang terencana dan terkonsep secara baik untuk meningkatkan kedisiplinan belajar siswa saat belajar di rumah (Home Learning). Pada kenyataannya masih terdapat siswa yang tidak bersungguh-sungguh dalam belajar dan masih ada beberapa siswa yang terlambat mengumpulkan tugas secara online. Oleh karena itu, pengenalan tentang efek serta pengaruh kedisiplinan saat belajar di rumah (Home Learning) dalam upaya meningkatkan hasil belajar siswa diharapkan dapat membantu sekolah maupun guru dalam menerapkan kedisiplinan belajar kepada siswa. Diharapkan dengan dilakukannya penelitian terhadap kedisiplinan belajar siswa saat dirumah, akan memberikan pengetahuan kepada sekolah, guru, maupun orang tua tentang pengaruh kedisiplinan belajar saat belajar di rumah untuk meningkatkan hasil belajar siswa. Sehingga dapat dilakukan upaya lebih lanjut untuk terus meningkatkan sikap kedisiplinan belajar siswa mengingat bahwasannya kedisiplinan memiliki pengaruh dalam meningkatkan hasil belajar siswa.

Motivasi dan kedisiplinan yang terdapat dalam diri siswa sebagai faktor utama untuk pencapaian hasil belajar yang baik. Namun tidak dapat dipungkiri apabila tingkat motivasi dan kedisiplinan pada setiap siswa itu berbeda. Akan tetapi pada kenyataannya faktor dari dalam diri saja tidak sepenuhnya menunjang pencapaian hasil belajar tanpa adanya dukungan dari guru dan orang tua sebagai pembimbing dalam proses belajar mengajar. Berdasarkan uraian di atas maka perlu dilakukan penelitian yang lebih mendalam tentang pengaruh motivasi belajar dan kedisiplinan saat Home Learning terhadap hasil belajar IPS kelas IV MI Al- Mursyidiyyah. 


\section{METODE}

Jenis penelitian yang digunakan yaitu jenis penelitian kuantitatif. penelitian ini dilakukan di MI Al-Mursyidiyyah kelas IV pada tanggal 24 Februari 2020 sampai dengan tanggal 6 maret 2020. populasi dalam penelitian ini adalah siswa kelas IV berjumlah 110 siswa dengan sampel berjumlah 85 siswa dengan menggunakan rumus Issac dan Michael. Pemilihan sampel menggunakan teknik Probability Sampling jenis simple Random Sampling. Ukuran sampel ditetapkan pada taraf kesalahan 1\%, 5\%, dan 10\%. Pengumpulan data menggunakan metode angket dan dokumentasi.

Uji instrumen data dalam penelitian ini menggunakan Uji Validitas dan Uji Reabilitas. Dan pengolahan data dalam penelitian ini menggunakan editing, skoring, dan tabulasi. analisis data yang digunakan adalah analisis deskriptif dan analisis infrensial/statisttik yaitu dengan menggunakan analisis regresi berganda.Sedangkan Uji F yaitu untuk mengetahui pengaruh yang signifikan variabel motivasi belajar dan kedisiplinan saat Home Learning terhadap hasil belajar IPS kelas IV MI AL-Mursyidiyyah tahun ajaran 2019/2020. Selanjutnya untuk mengetahui seberapa besar sumbangan antara variabel motivasi belajar dan kedisiplinan saat Home Learning terhadap hasil belajar IPS kelas IV MI AL-Mursyidiyyah tahun ajaran 2019/2020 secara relatif, yaitu dengan rumus sebagai berikut:

$$
S R \%=\frac{\alpha \sum \mathrm{xy}}{J \text { Kreg }} \times 100 \%
$$

Sedangkan untuk mengetahui seberapa besar sumbangan antara variabel motivasi belajar dan kedisiplinan saat Home Learning terhadap hasil belajar IPS kelas IV MI AL-Mursyidiyyah tahun ajaran 2019/2020 secara Efektif, yaitu dengan rumus sebagai berikut:

$\mathrm{SE} \% \mathrm{X} 1=\mathrm{SR} \% \mathrm{X} 1 \times \mathrm{R} 1$

$\mathrm{SE} \% \mathrm{X} 2=\mathrm{SR} \% \mathrm{X} 2 \times \mathrm{R} 2$

\section{HASIL DAN PEMBAHASAN}

Berdasarkan hasil analisis deskriptif diketahui bahwa variabel hasil belajar siswa kelas IV MI Al-Mursyidiyyah pada kategori tuntas yakni $71 \%$ dan kategori belum tuntas 29\%. Untuk Motivasi Belajar pada kategori sangat tinggi yakni 1\%, kategori tinggi 14\%, kategori sedang 21\%, kategori rendah $54 \%$, kategori sangat rendah $10 \%$.
Sedangkan variabel kedisiplinan saat home learning berada pada kategori sangat tinggi yakni $6 \%$, kategori tinggi 41\%, kategori sedang $22 \%$, kategori rendah $19 \%$, kategori sangat rendah $12 \%$.

Berdasarkan hasil prayarat analisis kuantitatif diperoleh hasil sebagai berikut: 
1. Hasil uji normalitas menggunakan SPSS Statistic 20.0 for Windows nilai Asymp Sig adalah 0,661. Nilai tersebut lebih besar dari 0,05 sehingga dapat dinyatakan bahwa data penelitian berdistribusi normal.

2. Hasil uji linieritas menggunakan SPSS Statistic 20.0 for Windows nilai sig F pada baris Deviation from linearity adalah bahwa variabel motivasi belajar memiliki nilai sig $\mathrm{F}$ $=0,108$, dan kedisiplinan saat Home Learning memiliki nilai sig F $=0,643$. Nilai tersebut lebih besar dari 0,05 sehingga dapat dinyatakan bahwa data penelitian bersifat linier.

3. Dari tabel di bawah terlihat setiap variabel bebas mempunyai nilai toleransi 0,985 $>0,1$ dan nilai VIF 1,015 < 10. Jadi dapat disimpulkan bahwa tidak terjadi multikolinieritas antara variabel bebas dalam model regresi ini.

Berdasarkan hasil analisis kuantitatif diperoleh hasil sebagai berikut:

1. Analisis Regresi Berganda

Berdasarkan hasil pengolahan data, maka dapat disusun persamaan regresi sebagai berikut:

$$
\mathrm{Y}=55,990+0,221 \mathrm{X} 1+
$$

$0,147 \mathrm{X}_{2}$.

artinya:

a) jika $X 1$ dan $X 2$ masing-masing 0 , maka $\mathrm{Y}=55,990$

b) jika X1 naik satu satuan dan $\mathrm{X}_{2}$ tetap, maka Y naik sebesar 0,221

c) jika $X_{2}$ naik satu satuan dan $X_{1}$ tetap, maka Y naik sebesar 0,147

2. UJI F

Berdasarkan hasil pengolahan data, diperoleh nilai $\mathrm{F}$ hitung $=4,229$, hasil tersebut jika dibandingkan dengan $\mathrm{F}$ tabel sebesar 3,110 pada taraf signifikansi 5\% naka nilai Fhitung $>$ Ftabel $(4,229>3,110)$. Apabila Fhitung lebih besar dari F tabel maka Ho ditolak, sehingga dapat disimpulkan bahwa terdapat pengaruh positif dan signifikan motivasi belajar dan kedisiplinan saat Home Learning secara bersamaan terhadap hasil belajar IPS.

3. Sumbangan Relatif (SR) dan Sumbangan Efektif (SE)

Berdasarkan hasil pengolahan data, diketahui bahwa motivasi belajar memberikan Sumbangan Efektif sebesar 5,47\% dan kedisiplinan saat Home Learning memberikan Sumbangan Efektif sebesar $3,83 \%$. Sedangkan motivasi belajar memberikan sumbangan relatif sebesar 58,77\% dan kedisiplinan saat Home Learning sebesar $41,23 \%$. 


\section{Pembahasan}

Motivasi belajar dan kedisiplinan saat Home Learning, kedua variabel tersebut dapat mempengaruhi hasil belajar siswa yang dalam hal ini yaitu hasil belajar IPS kelas IV MI AlMusryidiyyah. Siswa dapat mencapai hasil belajar IPS yang tinggi apabila dalam kegiatan belajar mengajar memiliki motivasi belajar yang tinggi dan memiliki sikap kedisiplinan yang tinggi pula. Kedua hal tersebut harus senantiasa berjalan beriringan dan terus dimiliki pada diri setiap siswa. Hasil belajar yang tinggi merupakan tujuan dari kegiatan pembelajaran yang dilakukan siswa.

Hal ini sesuai dengan pendapat Sardiman (2014) bahwa motivasi belajar sebagai pendorong usaha dan pencapaian prestasi. Seseorang akan melakukan suatu usaha karena adanya motivasi. Adanya motivasi yang baik dalam belajar akan menunjukkan hasil yang baik pula. Demikian pula apabila seorang siswa memiliki niat belajar yang baik dan dilakukan dengan baik maka akan mencapai hasil belajar yang maksimal. Dengan kata lain, adanya usaha yang tekun dengan didasari motivasi yang besar dalam diri siswa maka siswa yang belajar akan dapat menghasilkan hasil belajar dan prestasi yang memuaskan.

Hal tersebut juga relevan dengan penelitian yang dilakukan oleh Deni Anggih (2015) dalam penelitian tersebut menunjukkan ada pengaruh motivasi belajar terhadap prestasi belajar / hasil belajar. Hal ini membuktikan bahwa memang variabel motivasi belajar mempengaruhi variabel hasil belajar dengan adanya penelitian-penelitian yang telah dilakukan.

Berdasarkan hasil sumbangan efektif diperoleh informasi bahwa kontribusi motivasi belajar terhadap hasil belajar IPS sebesar 5,47 \% yang berarti masih banyak faktor lain yang berpengaruh terhadap hasil belajar disamping motivasi belajar.

Berdasarkan penelitian diperoleh sumbangan relatif bahwa tingkat motivasi belajar IPS siswa kelas IV tergolong dalam kategori cukup. Sebanyak 58,77 \% siswa dalam kateori cukup. Hal ini menunjukkan bahwa sebagian besar siswa mempunyai harapan dan cita-cita, kemandirian, ketekunan dalam belajar, senang mencari dan memecahkan soal-soal, kondisi lingkungan, dan upaya orang tua dalam membelajarkan anak.

Selain disebabkan oleh motivasi belajar, hasil belajar juga di pengaruhi oleh disiplin belajar. Berdasarkan hasil penelitian menunjukkan bahwa hasil sumbangan efektif diperoleh informasi bahwa kontribusi kedisiplinan saat Home Learning terhadap hasil belajar IPS sebesar 3,83 \% yang berarti masih banyak faktor lain yang berpengaruh terhadap hasil belajar disamping kedisiplinan saat Home Learning.

Hasil penelitian ini juga relevan dengan hasil penelitian yang dilakukan oleh 
peneliti lain yang tertuang dalam jurnal. Berdasarkan hasil penelitian dalam jurnal yang ditulis oleh Ryan dan Ade (2018) hasil penelitiannya menyatakan bahwa ada pengaruh positif dan signifikan disiplin belajar terhadap hasil belajar siswa.

Kemudian berdasarkan jurnal dari Zuhaira dan Subkhan (2015) membuktikan bahwa ada pengaruh yang positif dan signifikan kedisiplinan belajar terhadap prestasi belajar siswa. Namun berdasarkan hasil penelitian dalam artikel Rindo $a$ ah dan Dheasey (2018) menyatakan bahwa secara parsial negatife disiplin belajar mempengaruhi hasil belajar. Hal tersebut tidak relevan dengan hasil penelitian ini.

Berdasarkan penelitian diperoleh sumbangan relatif bahwa tingkat disiplin siswa saat Home Learning kelas IV MI AlMursyidiyyah tergolong dalam kategori cukup. Sebanyak 41,23 \% siswa dalam kategori cukup. Hal ini ternyata menunjukkan bahwa sebagian besar siswa sudah mempunyai sikap disiplin yang baik terlihat dari siswa memiliki disiplin waktu yang baik, siswa memiliki disiplin menjaga ketertiban dan kebersihan rumah pada saat menggunakan fasilitas belajar di rumah, siswa memiliki kedisiplinan belajar cukup baik, siswa memiliki sikap disiplin saat mengerjakan dan pengumpulan tugas cukup baik.

Berdasarkan analisis data yang telah dilakukan, menunjukkan bahwa terdapat pengaruh positif dan signifikan motivasi belajar dan kedisiplinan saat Home Learning secara bersamaan terhadap hasil belajar IPS kelas IV MI Al- Mursyidiyyah. Hasil analisis diperolah nilai koefisien korelasi $\left(\mathrm{R}_{\mathrm{y}}(1,2)\right)$ sebesar 0,306, koefisien korelasi tersebut bernilai positif maka terdapat pengaruh positif variabel motivasi belajar dan kedisiplinan saat Home Learning terhadap hasil belajar IPS. Nilai koefisien determinasi $\left(\mathrm{R}^{2} \mathrm{y}(1,2)\right)$ sebesar 0,093 atau $9,3 \%$ yang berarti bahwa motivasi belajar dan kedisiplinan saat Home Learning mampu menjelaskan 9,3\% perubahan hasil belajar. Sedangkan hasil uji F diperoleh nilai F sebesar 4,229. Hasil tersebut jika dibandingkan dengan Ftabel sebesar 3,110 pada taraf signifikansi 5\% maka nilai Fhitung $>$ Ftabel $(4,229>3,110)$. Besarnya sumbangan efektif motivasi dan kedisiplinan saat Home Learning secara bersamaan terhadap hasil belajar IPS kelas IV sebesar 9,3\%. Hal ini membuktikan bahwa motivasi belajar bersama kedisiplinan saat Home Learning cukup memberikan pengaruh terhadap hasil belajar IPS kelas IV MI Al-Mursyidiyyah. Pengaruh bisa berasal dari faktor yang lain yang dapat mempengaruhi hasil belajar IPS yang tidak diteliti oleh penulis misalnya faktor IQ (kecerdasan) siswa itu sendiri, daya tangkap siswa, guru dan metode mengajarnya, hubungan antara guru dan siswa, dan masih banyak faktor yang lainnya. Dan secara parsial motivasi belajar memberikan pengaruh 
sebesar 5,47\% dan kedisiplinan saat Home Learning memberikan pengaruh sebesar 3,83 $\%$. Kontribusi tersebut menunjukkan bahwa motivasi belajar dan disiplin belajar yang tinggi akan membantu meningkatkan hasil belajar siswa. Dari data tersebut di atas menunjukkan bahwa motivasi belajar lebih dominan memberikan kontribusi terhadap hasil belajar siswa daripada motivasi belajar.

\section{SIMPULAN}

Kesimpulan yang dapat diambil dari hasil penelitian dan pembahasan adalah terdapat pengaruh positif dan signifikan variabel motivasi belajar dan kedisiplinan saat home learning secara terhadap hasil belajar IPS kelas IV MI Al-Mursyidiyyah.

\section{REFERENCES}

Ahmad Syafi'i, dkk. Juli 2018. Studi Tentang Prestasi Belajar Siswa Dalam Berbagai Aspek Dan Faktor Yang Mempengarubi, Jurnal Komunikasi Pendidikan, Vol.2 No.2.

Aslanidou Eftychiai. 2019. Home Learning Activities And Children's Learning Outcomes: A Review Of Recent Evidence, European Journal Of Education Studies, Vol. 6 No. 1.

Deni, Anggih. 2015. Pengaruh Kedisiplinan dan Motivasi Belajar Terbadap Prestasi Belajar Praktik Kejuruan Siswa Kelas XI Teknik Pemesinan SMK Negeri 3 Yogyakarta. Yogyakarta.
Hal ini sesuai dengan pendapat Kompri (2015) tentang pentingnya motivasi dalam belajar. Dengan Adanya motivasi belajar dalam diri siswa tersebut sangat penting karena dengan adanya motivasi akan mendorong siswa untuk memiliki semangat dalam belajar dan melakukan suatu kegiatan yang akan menggerakkan diri dalam belajar untuk mencapai tujuan.

Hasil analisis dengan menggunakan SPSS 20.0 for Windows diperoleh $\mathrm{Ry}(1,2)$ sebesar 0,306 dan $\mathrm{R}^{2} \mathrm{y}(1,2)$ sebesar 0,093 yang berarti terdapat pengaruh positif motivasi belajar dan kedisiplinan saat home learning terhadap hasil belajar IPS kelas IV.

Kompri. 2015. Motivasi Pembelajaran Perspektif Guru dan Siswa. Bandung: PT.Remaja Rosdakarya.

Nana Sudjana. 2000. Dasar-dasar Proses Belajar Mengajar. Bandung: Sinar Baru Algesindo.

Natalia Ridwan, dkk. 2018. Home Learning: Belajar Seru Tanpa Batas. Jakarta: Gramedia Pustaka Utama. . 2014. Interaksi Dan Motivasi Belajar Mengajar. Jakarta: PT Raja Grafindo Persada. 
Soedijarto. 1993. Menuju Pendidikan Nasional yang Relevan dan Bermutu. Jakarta: Balai Pustaka.

Sumadi Suryabrata. 2006. Psikologi Pendidikan. Jakarta: Rajawali.

Tu'u, Tulus. 2004. Peran Disiplin pada Perilaku dan Prestasi Siswa. Jakarta: Grasindo. Uno. 2011. Teori Motivasi dan Pengukurannya. Jakarta: Bumi Aksara.

Yusuf. 2003. Motovasi Dalam Belajar. Jakarta: P2IPTK.

Zuhaira, L.K,\& Subkhan. 2015. Pengarub Motivasi Belajar dan Kedisiplinan Belajar Tehadap Prestas Belajar Siswa.Kelas XI IPS SMK N 3 Pati Economic Education Analysis Journal
Rindo"ah, \& Dheasey, A. 2018. Influence Of Learning Discripline, Methods Of Teaching Teachers And School Facilities On Improving Student Achievement SMK Negeri 1 Pringapus. Semarang. Diakses pada 28 November 2018, pukul 18.14 WIB.

Rusman. 2015. Pembelajaran Tematik Terpadu. Jakarata: PT Raja Grafindo Persada. Ryan, P, \& Ade, R. 2018. Pengaruh Disiplin Belajar, Lingkungan Keluarga, dan Motivasi Belajar Tehadap Hasil Belajar Siswa. Economic Education Analysis Journal.

Sardiman A.M. 1992. Interaksi dan Motivasi Belajar Mengajar. Jakarta: Rajawali Pers. 